\title{
The Warrior and the State in Precolonial Africa
}

\author{
Comparative Perspectives
}

G. N. UZOIGWE

The University of Michigan, Ann Arbor, U.S.A.

\section{Introduction}

$\mathrm{P}$

REPARING this chapter was at once intimidating and challenging -intimidating because I have no models to draw from; and challenging because it needed to be done. More significantly, it needed to be done by an Africanist historian. For the days, alas, are gone when such subjects were comfortably left to the nutty anthropologists while historians in their lonely and crusty arrogance, exuded effortless superiority in dusty libraries and archives in a vain attempt to discover the "truth" about the past. "Hard history," difficult enough as it is, is a much more straightforward and simpler affair than the "new history". As our mentors were taught so did they teach us. The result is that most historians of our generation are not properly equipped with the disciplines of anthropology and sociology as well as the other relevant social sciences which are crucial to African historical reconstruction. For a good Africanist, in whatever field, must be a jack-of-all-trades and master of one. The truth is perhaps that few of us are really master of anything at all - whatever we may claim. It is possible that I am really describing myself and no one else. Whatever is the case, I must begin this chapter with an apology relative to whatever weaknesses it may have.

At a recent international conference on the military in Africa held in Accra, Ghana, ${ }^{1}$ a pet idea of mine received unsolicited support, namely, that a military interpretation of African history ought, at least, to be as rewarding as the economic or any other interpretation for that matter. This idea, however, was clearly implied, but not theoretically focused, in the several papers presented. But it was the general consensus that in precolonial African states, characterized, except in a very few cases, by the lack of visible armies, the distinction between the military, economic, political, social and religious institutions of government were blurred. It follows, therefore, that the historian

1 This conference, entitled African States and the Military: Past and Present, was held under the joint auspices of the African Studies Centre, U.C.L.A. and the University of Ghana in August, 1975. 
who studies the African military as distinct from socio-politico-economic structure does so at his peril. And granted also that there have been discontinuities and continuities in African institutions under both the colonial and postcolonial epochs of African history, it follows, too, that studies of the African military in the twentieth century ought to benefit significantly from its preEuropean antecedents. This is a point to which sociologists and political scientists are only now beginning to turn attention. Their predecessors, indeed, were roundly accused in a perceptive, if at times contentious, contribution by René Lemarchand ${ }^{2}$ at the Accra conference referred to above of being "unduly selective in their use of history". Their contributions, he suggests, inevitably lack historical depth precisely because "their treatment of the African military shows remarkable regard for historically relevant facts". Such scholars, in short, are wont to react like Johann von Bloch who asked with rhetorical naivery in his The Future of War (1898): "What is the use of talking about the past when you are dealing with an altogether new set of circumstances?"3 Although historians, too, have begun to make a plea for a change in this orientation towards the study of the African military, ${ }^{4}$ they are equally accused of preoccupation "with the unique and the specific," of lacking a theoretical framework, and of a tendency to let their imagination run away with them. ${ }^{5}$ There is some truth to this accusation. It must be pointed, however, that historians are loath to theorize without empirical data; and given the present rudimentary state of precolonial African military studies, ${ }^{6}$ their emphasis has been on the accumulation of the relevant data. This is not to suggest that they are unwilling to profit from any meaningful framework that the social scientists may provide. There is, therefore, no serious conflict - or, at any rate, there ought not to be a serious conflict - between historians and social scientists on this subject. Both approaches should complement each other. This means that a useful study of the African military must, of necessity, be interdisciplinary and comparative. It is, of course, true "that, as a substantive area of study, the military in Africa has been largely preempted by sociologists and political scientists;" " the fact remains, nevertheless, that no discipline can effectively dominate the field. Theories without data, and data without theories, if clothed with the garb of academic respectability, will be a very undesirable development in African studies.

And yet the very area of data collection in the precolonial period where, in my opinion, the historian is expected to make an important contribution, has

2 See "African Armies in Historical and Contemporary Perspective: The Search for Connexions (sic)".

3 Cited Lemarchand, "African Armies," loc. cit.

4 See G. N. Uzoigwe, Revolution and Revolt in Bunyoro Kitara: Two Studies (Longman: 1970), pp. 1-29; idem, "Precolonial Military Studies in Africa", The Joumal of Modern African Studies, 13, 3 (1975), pp. 469-481; cf. B. A. Ogot (ed.), War and Society in Africa: Ten Studies (London, 1972).

5 Lemarchand, "African Armies", loc. cit.

6 Uzoigwe, "Precolonial Military Studies in Africa", loc. cit.

7 Lemarchand, "African Armies", loc. cit. 
presented him with immense problems. It is, therefore, easy to understand why historians, for so long, have deliberately avoided the study of this sub-ficld of the historical discipline. To begin with, that the societies with which they are concerned kept no written records of their military establishments or of their military achievements made the task almost an impossible one especially during the era when oral tradition was not taken seriously by classical historians. With the acceptance of oral tradition - scientifically collected and applied - as a legitimate concern of historical writing, the problem has abated somewhat. We know, however, that oral tradition is most unrcliable when dealing with the military exploits or martial spirit of a given society. And yet, if the military has been studied as socio-political structure, the problem would have been no more difficult than the general problems of precolonial African history.

In this study of the warrior and the state in Africa, I have relicd on first, oral tradition. It must be kept constantly in mind that most of these sources are "free texts" with an overlay of nationalistic jingoism and a tintinnabulation of moral righteousness. ${ }^{8}$ Second, travel lore. These comprise the published works of nineteenth century European travellers, traders, explorers, missionaries and administrators. These sources, too, are based, in large part, on oral testimonies and should, consequently, be used with care. Third, ethnographic data. These are also based on oral tradition, oral testimonies, and sometimes on personal observation. They are variably informed but sketchy. And fourth, published and unpublished materials on precolonial African military history including my own previous studies. It is hoped that a judicious use of these studies might enable us to gain some insight into the relationship between the warrior and the state in precolonial Africa, and perhaps help to put the "myths" which we love so much and for which we have been for long maligned in historical perspective.

Given these sources, there are, of course, several ways of approaching the relationship between the African warrior and the state as a unit of analysis. I have opted for the structural-functional analysis as the most meaningful approach. This is in keeping with my conviction that the military must be studied and comprehended as socio-political structure. I am not, therefore, concerned with the impressions or images of warriors. Most societies - indeed all societies have concepts of masculinity, bravery, love of country, love of honour, and martial spirit. But there is no society which is either totally pacifist or totally aggressive. I am suggesting that war, or the use of naked force to achieve desired goals, has proved to be a permanent feature of human society. It is as old as the world and, therefore, older than history. The warrior, the fighting

8 The major traditions I consulted include John W. Nyakatura, Anatomy of an African Kingdom: A History of Bunyoro Kitara (New York: 1973), ed. G. N. Uzoigwe; Kabalega and Winyi, "The Kings of Bunyoro-Kitara" in three parts, Uganda Journal, 3 (1935), pp. 155160; 4 (1936), PP. 75-83; 5 (1937), pp. 53-68; A. B. (Ruth) Fisher, Twilight Tales of the Black Baganda (London: 1911, 2nd ed. 1970), pp. 69-178; Apolo Kaggwa, The Kings of Buganda (Nairobi: 1971), ed. M. S. M. Kiwanuka; A. T. Bryant, Olden Times in Zululand and Natal (London: 1938); Samuel Johnson, The History of the Yorubas (London: 1921; reprinted 1969). 
man, the man of action, is always the executor of violence but not necessarily always its originator. He is, in the contcxt of the state, the instrument of political action. Wars are never fought for illusory ends. States fight for a variety of reasons: survival, power, wealth, prestige, sex and so forth. In precolonial African states, therefore, where the state and the military were fused, the study of the warrior is, in essence, the study of the state. But yet not everyone, strictly speaking, was a warrior. This study, therefore, is concerned with the very difficult task of (a) isolating those aspects of precolonial African state organisation that have a discernible military function; (b) of identifying the function of the warrior in that context; and (c) of comparing this structural-functional aspect of the warrior in several African state systems.

\section{The Warrior as a Political Animal}

In no state, traditional or modern, is the military totally divorced from the political structure. The degree of integration, however, between the military and politics varies from state to state. It follows, therefore, that the warrior tradition, in the sense I conceive it, cannot be uniform. But this is not to suggest that dramatic differences necessarily existed. The warrior, in a traditional society, was a political animal, more so than the rank and file of the citizenry. He saw politics as state power; he knew that the art of politics concerns how to acquire that power, how to wield it effectively, and how to preserve it. Most importantly, he knew that the surest means of achieving state power is through the agency of the warrior. Since a considerable number of precolonial African states were conquest states, the integration of the military and politics, as well as the invocation of warrior values in these states, was carefully cultivated along with the construction of historic - invariably mythical-charters with an overlay of the divine right of rulers in order to ensure the survival and viability of these states. Even among non-conquest, invariably non-kingdom, states, the function of the warrior was, indeed, assured. We shall examine the theme of the warrior in politics under the following sub-categories: the relationship between the ruler and the warrior class; the function of the warrior in territotial administration; and the impact of the rise of the professional warrior on the primordial state. We shall draw our illustrations primarily from the Zulu, Bunyoro Kitara and Buganda, Oyo and the Yoruba states, and Kikuyu, indicating differences and similarities where appropriate.

The political organisation of the Zulu before 1800 did not differ markedly from those of small scale, precolonial African societies which evolved a chiefly system of government. Warfare appears to have been rare, and when it did occur, it was usually a struggle for power between a chief and his relatives. ${ }^{9}$ The

9 E. A. Ritter, Shaka Zulu: The Rise of the Zulu Empire (London, 1955: reprinted New York 1973), pp. 22-23; Max Gluckman, "The Kingdom of the Zulu of South Africa" in M. Fortes and E. E. Evans-Pritchard (eds.), African Political Systems (New York: 1940), p. 25; M. Gluckman, "The Individual in a Social Framework: The Rise of King Shaka of Zululand," Joumal of African Studies, 1, 2 (1974), pp. 124-125. 
civil war in Zululand between 1808 and 1818 significantly changed the situation. For one thing, it brought about enlargement of political scale; for another it began a tradition of militarism among the Zulu which exists to the present day. Shaka's much vaunted revolution is, in fact, not as original as his numerous admirers like to suggest. It has, indeed, been noted that "he duplicated in his great new nation early Nguni tribal organization, though on a much larger scale and with a deeper hierarchy of officials." 10 The political organisation of the pre-Shaka Nguni state, like those of the other southern Bantu states, was headed by a hereditary chief, assisted by sub-chiefs - usually members of the royal family - who administered the districts as well as by other officials called indunas. The senior indunas had also the rank of deputy chief. The indunas were powerful officials and were not chosen from among the ranks of the royal eligibles to the throne. The chief and his officials were commanders of their people in war and political leaders in war and peace. A chief was usually a great warrior, and his officials were appointed, in large measure, as a result of their military valour. In the pre-Mfecane Zulu state, therefore, the military and politics were dangerously fused. The ordinary citizens had no means of removing an unpopular government. Of course, a "palace revolt" sometimes occurred, but the system of government did not change. This is very reminiscent of contemporary military-cum civil dictatorships in Africa.

The interlacustrine states of Bunyoro Kitara (popularly known as Bunyoro) and Buganda have also a long tradition of the warrior in politics. In the first instance, both are, according to their traditions, conquest states. In the process of consolidating their hold on the newly acquired territories, the Omukama of Bunyoro and the Kabaka of Buganda had no choice but to invoke warrior values and construct historic charters in the process of legitimacy engineering. As the last Kabaka of Buganda, the late Sir Edward Muteesa, put it with respect to Buganda: "The word Kabaka means "emissary", and some time in the past an overseer sent from Bunyoro had set himself up as an independent ruler. For a long time we struggled for survival, surrounded by larger neighbours, existing like a garrison state; and herein lay our strength." 11 In Bunyoro, too, the word "Kitara means a sword but has historically come to signify an empire worn by the sword by individuals possessed of excessive virtue." 12

At this early stage, the ideal king was the great warrior, larger than life. The military activities - or supposed military activities - of these kingdoms are eloquently recorded in the traditions. The dominant picture that has emerged from these sources is that the political history of the interlacustrine states of east Africa is, in large measure, a study of the Abachwezi Kitara empire and the struggle for mastery following its collapse between Bunyoro and Buganda. It is understandable, therefore, why in states such as these the military was

10 Gluckman, "Individual in a Social Framework," p. 134.

11 Sir Edward Muteesa, Desecration of My Kingdom (London: 1967), p. 30.

12 G. N. Uzoigwe, "Bunyoro Kitara in the North Interlacustrine Region," in S. Kiwanuka and A. Temu (eds.), East African Kingdoms (forthcoming). 
destined to play a crucial role. But like the Nguni state, too, the military was not distinct from the political structure: it followed closely the organisation of the state. There was, constitutionally (in either kingdom), a monocephalous kingship which, as both a centrifugal and centripetal force, was at the apex of the political order. Authority flowed from the king to the abakungu (territorial administrators). These abakungu were assisted by a hierarchy of deputies who, together with their immediate overlords, were expected to provide warriors for their king's wars. Traditionally, the abakunguship was not necessarily hereditary. Such an appointment was usually a reward for military valour. Bunyoro tradition, indeed, maintains that originally only outstanding warriors were made abakunga. ${ }^{13}$ Neither in Bunyoro nor in Buganda was a cowardly chief likely to retain his position for long. Although in Buganda the danger of a successful omukungu (singular of abakungu)-cum-general overthrowing the Kabaka was unthinkable since he was neither a prince nor a royal eligible, yet the possibility remained that he could be wooed by a royal pretender to the throne to help him overthrow the incumbent Kabaka. Therefore, before a commanding general left for the battlefield, he was expected to leave behind with the Kabaka a precious hostage. ${ }^{14}$ In Bunyoro, on the other hand, where the danger of secession was ever present especially as a considerable number of the most important abakungu belonged to the royal family, the Omukama took steps to ensure that his omukungu-cum-general would not be contumacious, or more seriously, seditious. ${ }^{15}$ The history of Bunyoro is full of examples which illustrate that he did not always succeed. It was, however, during succession and civil wars ${ }^{16}$ that these civil-military administrators exerted the decisive political impact.

In a general sense, the political organisation of the Yoruba state systems resembled that of the Kitara empire. There is the Alafin of Oyo who was regarded as "the supreme head of all the kings and princes of the Yoruba nation" 17 who traces his descent to Oranyan, the supposed founder of the old Oyo empire. At the height of Oyo power these kings and princes are estimated to have numbered 1060. But according to Johnson, however, "The word 'king'" included "all more or less distinguished chiefs, who stand at the head of a clan, or one who is the ruler of an important district or province, especially those who can trace their descent from the founder, or from one of the great

13 Uzoigwe, Revolution and Revolt, p. 1.

14 John Roscoe, The Baganda (London: 1911; 2nd ed., 1965), p. 350.

15 John Roscoe, The Banyoro or Bakitara (Cambridge: 1923), p. 52 ; John Beattie, The Nyoro State (Oxford: 1971), pp. 137-138; 4. idem, Bunyoro: An African Kingdom (New York: 1960), p. 36.

16 For succession and civil wars in Bunyoro and Buganda see G. N. Uzoigwe, "Succession and Civil War in Bunyoro Kitara," The International Journal of African Historical Studies, VI, 1 (1973), pp. 49-71 ; Martin Southwald, "The History of a History: Royal Succession in Buganda," in I. M. Lewis (ed.), History and Social Anthropology (London and New York: 1968), pp. 127-151.

17 Johnson, History of the Koruba, p. 41. 
leaders or hereos who settled with him in this country." They all owed allegiance "to the Alafin or king of the Yorubas."18 In the context of the Kitara empire, therefore, most of the abakunga would qualify as kings in the Yoruba usage; and the position of the Alafin resembles that of the Omukama of Bunyoro.

Apparently, before Oranyan who has been described as "primarily a political adventurer," 19 the Yoruba had no common political head. It was Oranyan, also reputed as "a very brave and warlike prince" who, after the foundation of Oyo, had set in motion the political federation of a congeries of chiefdoms and principalitics which appear to have exhibited a remarkable cultural homogeneity. He is said to have started his campaign with a bodyguard of " 150 welltrained soldicrs." 20 The Oyo empire, therefore, like those of Bunyoro, Buganda, and Zulu was also a conquest state from whose inception the military played a crucial role. The warrior ideal was relentlessly cultivated. The Alafins, like the earlier Abakama of Bunyoro, were required to be great warriors and to exhibit militant leadership as well. Alafin Ajaka, for example, was deposed by the Oyo Mesi (Council of State) for his lack of militarism and replaced by Sango, Oranyan's son, who was known to have demonstrated warlike characteristics. It is interesting to note that when Sango died prematurely and Ajaka was given a second chance, he proved to be more warlike than his predecessors. Oyo became the terror of its neighbours as it established overlordship over the other Yoruba state systems. The relaxation of the warrior tradition in subsequent reigns led to the defeat of Oyo by Nupe. The reigning Alafin, Onigbogi, fled to exile. The exile of the Alafins lasted for 75 years. While in exile, the Alafins of Oyo revived their warrior tradition, restoring eventually the military might of Oyo and reoccupying Old Oyo around A.D. 1610.21

To ensure that the disaster which occurred in the reign of Onigbogi was not repeated, the Alafins of Oyo began a policy of military reorganisation and militant expansion of Oyo influence. Conquered areas were placed under the effective administration of the Ajele (political residents). It was during this period that Alafin Ajagbo created the position of Are Ona Kakanfo (Generalissimo of Oyo's army). The Kakanfo (as he is popularly known) was expected to wage war regularly, to win each war "within three months or be brought home dead." 22 By mid-eighteenth century Oyo had become the largest state system in Yorubaland. It had also become a military machine which, if not properly controlled, could prove dangerous for political stability.

Constitutionally, Oyo was a semi-divine monarchy ruled by an Alafin whose

18 Idem.

19 See J. A. Atanda, "The Military in the Politics of the Old Oyo Empire," paper presented at the Accra Conference, August 1975; $f f$. Johnson, History of the Yorubas, pp. 143-148 for Oranyan's career.

20 Ibid,

21 R. S. Smith, "The Alafin in Exile: A Study of the Igboho Period in Oyo History," Journal of African History, VI , 1 (1965), pp. 57-77.

22 Atanda, "The Military in Politics," loc. oit. 
power, in theory, was absolute; in practice, however, his authority was subject to checks and balances by the Oyo Mesi. Unlike his eastern and southern African counterparts, the Alafin was obliged to carry out the decisions of the Oyo Mesi or commit suicide. The Bashorun, as leader of the Oyo Mesi, was a very powerful person but he did not exercise absolute power either. Nor did the great Ogboni chiefs whose head was called Oluwo. The Oluwo checked the ambitions of the Bashorun who, in turn, checked the ambitions of the Alafin. And none of these three powerful leaders had individual control over the Kakanfo and his corps of 70 standing army officers called the Esos. But the Kakanfo, too, was forbidden to live within the capital. The idea was to cut him off from possible dangerous influence over the Esos who lived there. The Esos were clistributed equally (ten each) among the seven members of the Oyo Mesi and put under their control. No single individual, therefore, could use the army to achieve his objectives. The Oyo Mesi, by having corporate control of the army, could also check the ambitions of the Oluwo and his Ogboni.

This complex and delicate political balance was upset when a change in the succession to the throne increased the powers of the Bashorun at the expense of those in charge of the other arms of government. It is said that cluring the third quarter of the eighteenth century Bashorun Gaha, using his new powers, was able to set up five Alafins, four of whom he destroyed. Having subverted the constitution, he ruled despotically for 20 years but somehow he could not gain exclusive control of the military. His power collapsed when an apparently puppet Alafin called Abiodun secretly plotted with the Kakanfo and the provincial chiefs to bring about his overthrow. The constitution was, therefore, restored by military intervention and Gaha was burnt at the stake. Coup d'etats alwavs tend to be a way of life once introduced into the political system. Oyo was no exception. It was the coup led by Kakanfo Afonja which set in motion the trend of events which eventually led to the total destruction of the Oyo empire in $1837 .{ }^{23}$ It is ironic that the political system which took very carefully calculated measures to avoid a coup eventually fell by it.

The army, then, was a very important instrument in the rise and fall of the Oyo empire. But Oyo was not a military state. The 70 Esos divided into seven equal parts did not constitute much of an army. The military and politics were still dangerously fused and the ordinary citizens were ready pawns in whatever power politics their leaders might choose to initiate. Little is known about the military in the other Yoruba states which numbered 39 by the nineteenth century. We know, however, that the Elegbe (military chiefs) of eastern Yoruba formed a distinct category from the civilian chiefs, that their influence was minimal during peacetime, and that they posed no threat to constitutional, political authority. ${ }^{24}$

23 Ibid; Johnson, History of the Yorubas; J. B. Webster and A. A. Boahen, The Revolutionary rears: West Africa Since 1800 (London: 1967), pp. 92-95.

24 S. A. Akitoye, "The Military Among the Yoruba of South-Western Nigeria in the Nineteenth Century," paper presented at the Accra Conference, 5 August, 1975. 
According to the mythical constitution of the Kikuyu - which abolished "the status of a king or nobleman" - government was the responsibility of the Kiama (councils of elders). The Kiama were all retired warriors. The military, then, was a training ground for political office. The Anake or warrior class consisted of young men between the ages of eighteen and forty. This very important class formed the njama ya ita (council of war) which, in addition to "its military activities, represented the interests of the young people in the government." 25 The Kikuyu system of government as well as its military organisation was more democratic than the others we have discussed so far. Kikuyuland was a nonkingdom state in which the warrior was a political animal par excellence. From his early years, a youth knew that to reach the coveted position of membership of the Kiama - and more importantly to be able to influence its deliberations he must strive to achieve reputation as a great warrior. The warrior tradition, therefore, as a way of life, was institutionalized. In such a system, the military overthrow of the government did not make sense and apparently was never attempted. The Kiama was continuously changing as a result of new additions through the age-grade system or as a result of the death of some of the existing members.

The African warriors were, therefore, from the examples we have seen, an indivisible element of the central government. But since they were also military leaders as well as administrators, they played crucial roles in territorial administration. In the kingdom states, it was the duty of the civil-military administrators of provinces to provide soldiers for their king's wars while the king undertook to protect them and their provinces from both internal and external attack. The king was their commander-in-chief; they were the king's generals; and their deputies could be ranked in descending order from what might be the equivalent today of brigadiers to lieutenants. The rest of the population comprised the citizen militia; the so-called invisible armies. Failure to support their king during a military emergency constituted a rebellion. Such a rebellion might succeed or collapse depending on the alignment of political forces in the country. Sometimes a successful rebellion resulted in secession and the foundation of a new kingdom especially if the rebellions commander was a prince and a royal eligible.

This was particularly true of Bunyoro where the defence of the kingdom was the responsibility of the obwesengeze 26 (territorial armies) which were under the direct command of their civil-military administrators. They were, in essence, private companies who owed nominal allegiance to the Omukama through these territorial administrators. The Omukama, too, had his own private companies, or palace guards, but they were not strong enough to determine the outcome even of internal conflicts. In such a situation his terri-

25 Jomo Kenyatta, Facing Mount Kenya (London: 1938; N. York: 1965), p. 187.

26 Obwesengenze is a Luganda word. The Banyoro used it to denote personal possession with all rights of disposal. The Runyoro equivalent is abahinya. My Banyoro informants, however, seem to prefer the Luganda variety. In the context in which it is used in this essay, the territorial armies were considered to be the personal possession of the military chiefs. 
torial administrators, who behaved as kings, except in name, were potentially dangerous. In any political structure, then, where the civil-military administrators of provinces form the basis of military organisation, the position of the central government was bound to be weak. This was the dilemma of the Bunyoro kingdom prior to the rise of Kabalega. ${ }^{27}$ In Buganda, too, the territorial administrators, like their compatriots in Bunyoro, by being civil-military leaders, exercised tremendous impact on historical movements in their kingdom. Admittedly, they were not royal eligibles but they could combine, under the umbrella of a royal eligible, to depose a ruling Kabaka; admittedly, too, the position of the later Kabakas was, at any rate, in practical terms, stronger than that of the later Abakama of Bunyoro with the exception of Kabalega. Nevertheless, the Buganda territorial rulers were also the accredited defenders of their kingdom and literally owned all the individuals living within their territorial limits. ${ }^{28}$ In either kingdom it was the mystique of kingship and the monarch's ability to manipulate different interest groups - and not the actual military force wielded by him - which ensured stability. The source of military strength of a civil-military administrator was ultimately all the able-bodied citizens who constituted the fighting force. In wartime, they fought under his banner; in peacetime, they belonged to him, although, in theory, everybody belonged to the king. They were by no means serfs since they did not cultivate the fields for their lords. Cultivation, generally, was done by women. The male citizens constituted, rather, a militia who served directly the ambitions of their civil-military overlord. The function of the warrior in territorial governance in Zululand and Yorubaland prior to the nineteenth century did not differ dramatically from that obtained in Bunyoro and Buganda and should not, therefore, detain us. ${ }^{29}$ Among the Kikuyu, on the other hand, the variation is worth emphasizing. The anake (warrior class) was divided into senior warriors and junior warriors. Kenyatta describes their governmental function thus:

Each group had its village, district and national leaders (athamaki a riika), who acted as spokesmen in all matters concerning the welfare of the groups and the tribe. These leaders were chosen by their particular groups at general or public assembly. They were men who had proved by their own actions, their capability of leadership; had shown bravery in wars, impartiality in justice, self-sacrifice, and above all, discipline in the group. A man with these qualities was able to attain a high position and esteem in the community, especially when he had retired from the activities of a warrior. Judges and responsible elders... were chosen from such men. ${ }^{30}$

27 See G. N. Uzoigwe, "Kabalega and the Making of a New Kitara," Tarikh, 3, 2 (1970), pp. 5-20; $c f$. reprint of same in Obaro Ikime (ed.), Leadership in 19th Century Africa (London: 1974) pp. 000.

28 C. C. Wrigley, "The Changing Economic Structure of Buganda," in L. A. Fallers (ed.), The King's Men (London: 1964), pp. 21-22.

29 Those interested in pursuing the subject further should consult for Zululand Gluckman, "The Kingdom of the Zulu," loc. cit.; idem, "The Individual in a Social Framework," loc. cit.; Ritter, Shaka Zulu, op. cit.; Bryant, Olden Times in Zululand, op. cit. And for Yorubaland, Johnson, History of the Yoruba, op. cit.; Atanda, "The Military in Politics," loc. cit.; R. S. Smith, Kingdoms of the Yoruba (London: 1969).

30 Kenyatta, Facing Mount Kenya, p. 192. 
What emerges from the Kikuyu system as described by Kenyatta is a government founded on the principle of division of functions with harmony, stability, respect, age, and lack of individualism as its most cherished characteristics. Underspinning all these characteristics was the ideology of the warrior as the bedrock of statehood.

The Kikuyu system did not clrange until the advent of British rule. Within the kingdom states we have discussed so far, however, tremendous changes occurred during the nineteenth century, a century characterized by revolutions, transition, and change. One of the revolutions pertained to the military; and the basic military revolution was the rise of professional and standing armies. Hitherto, such armies were rare in Africa. The new armics challenged established authority or restored it as the case might be, subverted the constitution or ignored it, enlarged the political scale or decreased it, and brought about stability or created instability. And to add to the revolutionary situations that existed, the new-style warriors came increasingly to employ the use of firearms.

Among these developments the bantu revolution in southern Africa is the most celelorated by historians. The Zulu empirc of Shaka which his successors Dingaane, Mpande, Cetewayo, and Dinuzulu - somehow managed to lose, is a good example of a conquest state in which this new-style warrior was dominant and which institutionalized and invoked both the reality and myth of warrior values. We have already noted that Shaka improved and enlarged what he inherited without necessarily destroying the basic organisation of society. "Dingiswayo", indeed, "played Philip to Shaka's Alexander" as Ritter suggests, ${ }^{31}$ but Shaka militarized the politics of the state more than any leader in Africa before him. The Zulu state was now organised along military lines; the king depended almost entirely on the military indunas who, in turn, depended on their impis. Those warriors, together with their commanders, were grouped by age, quartered in barracks, and forbidden to marry before they retired from the military. Their influence was such that the old aristocracy of chiefly indunas, by now means abolished, quickly became a cypher in politics. It is doubtful, however, that in the post-Shaka era there was a chiefly induna who was not a retired warrior, very much in the Kikuyu tradition. The Zulu king, himself a respectable military leader, remained, nevertheless - much in the tradition of contemporary military dictatorships in Africa - both a centrifugal and a centripetal force in the state. In legal theory he owned all the land and exercised unrestrained sovereignty over all his people. His official title of Nkosi was also the official name of the National Parliament or the Royal Assembly just as in Bunyoro the name Obukama means kingship or the state and the name Omukama means the king. In practice, however, this sovereignty was subjected to various and subtle checks and balances prescribed by custom and dictated by political realities. Not even the great Shaka - before he became practically insane with power or grief or both - could afford to act outside of the law. And when he did so, he paid with his life.

31 Ritter, Shaka Zulu, p. 41. 
The survival of the Zulu state therefore as well as the survival of the king himself depended on the alliance between the king, the standing army of warriors, and the chiefly indunas. In this alliance the warrior was dominant. Shaka knew, in his years of sobriety, that without his warriors he was nothing. That was why he spared no efforts to please them. And to ensure that the elite among his warriors did not become overmighty subjects - as Mzilikazi Kumalo attempted to be afterwards - he militarized the entire population including all traditional ceremonies. The idea of individuals living in military barracks, built like ordinary Zulu homesteads but containing thousands of men under arms was mind-boggling at the time. These barracks were, in addition, regarded as royal homesteads. The age-regimental system, introduced by Dingiswayo, but perfected by Shaka, was used to ensure the total submission of the people to military authority. ${ }^{32}$ A new regiment was created each year as the occasion arose until Zululand became a military camp; and politics became, not the art of the possible, but the art of the strongest.

The strongest was the warrior; and the king and commander-n-chief was the strongest and bravest warrior of them all. He punished and pampered his warriors - as the occasion demanded - with equal exuberance. "The secret of Shaka's "popularity", Ritter has noted, "was his great liberality to his soldiers at the expense of his tributary chiefs and the personal attention he gave to the needs of his warriors." And "like his contemporary, Napoleon, who told his soldiers that they each carried a Field Marshall's baton in their knapsacks, Shaka let his warriors know that there was no limit to their promotion, irrespective of their clan or social status, provided only that they had proved their merit." ${ }_{33}$ Shaka, however, did not tolerate civil jurisdiction over the army; the responsibility of dealing with his warriors was his alone. ${ }^{34}$ The Zulu state resembled the timarchic state of Sparta although Spartan warriors were allowed to marry. "A man," writes Gluckman, "was called isihlangu senkesi (war-shield of the king). The dominant values of Zulu life were those of the warrior and they were satisfied in service at the king's barracks and his wars." 35 Nothing else, apparently, seems to have mattered.

The repercussions of Zulu militarism in Bantu Africa were enormous. Warrior institutions and values a la Shaka spread like wildfire throughout south

32 Perhaps it is worth pointing out at this point that at the Accra Conference referred to above, one of the suggestions (relative to the best means of putting a stop to the epidemic of military coups in Africa) which produced the most hilarious reception was the abolition of the present structure of the African military and the compulsory arming of every citizen. It was felt that Africans everywhere are being totally submitted to military authority.

33 Ritter, Shaka Zulu, pp. 99-100.

34 Ibid., p. 270.

35 Gluckman, "The Kingdom of the Zulu," p. 31. It is interesting to note that as early as 1918 W. S. Fergusson compared the Zulu and Spartan military system. See Fergusson, The Zulus and the Spartans: A Comparison of Their Military Systems (Cambridge, Mass.: 1918). 
central and east central Africa. These institutions and values were modified to suit differing situational factors. And warrior values, at any rate, persist to the present day within, of course, the limitations imposed by harsh, European minority overlordship. It has also been pointed out that during the "early colonial period the tradition of the Mfecane ... played an important part in determining psychological attitudes to white rule." 36 For example, the Ndebele revolts in Southern Rhodesia (1896-1897), the revolt of the Zulu against white rule (1906), the Maji Maji revolt against the Germans in which the Ngoni (who inrupted into East Africa under the leadership of Zwangendaba during the Mfecane) played an active part, were all influenced, in large part, by the traditions of the Mfecane. So also were the millenarian and nationalist liberation movements in southern Africa. ${ }^{37}$ The Ndebele and the Ngoni regard the nineteenth century as a golden age in their history destroyed by the imposition of European rule.

The rise of a professional warrior class in Bunyoro and Buganda during the second half of the nineteenth century proved momentous in the history of both kingdoms. The creation of the abarusura (national standing army) by Omukama Chwa II Kabalega of Bunyoro was a direct challenge to the military power of the civil-military administrators. It denuded the territorial obwesengeze of able and ambitious young men, anxious to improve their lot, who enlisted in the national army to serve their king, enrich themselves, and help to defend their country. Whether Kabalega knew it or not, and whether the civil-military administrators realized it or not, the creation of the abarusura was constitutionally fundamental for it amounted to a drastic change in power relations in Bunyoro. The professional warrior, not the good old warrior-politician, had now become the backbone of the new power in the land. And he was used by Kabalega to ensure the ascendancy of royal, over aristocratic, power. The territorial administrators remained, nevertheless, a relic of the old political order, performing now the dreary functions of collecting the king's taxes and settling disputes. They also still retained their military obwesengeze who acted as reserve warriors to be called up by the king during an emergency. The abarusura, on the other hand, were precluded from exercising, at any rate, direct political power. Nevertheless, under Kabalega, Bunyoro was an armed camp. The military, without having a clear political role, was nevertheless dominant in politics. ${ }^{38}$ The soldiers threw their weight about and quickly gained a bad reputation. ${ }^{39}$ Gaetano Casati, who was a prisoner of the abarusura recorded: ". . . the power of the banassura (sic) in the government was assured. The owners of the land were deprived of every customary right ... the military party became preponderant in Unyoro ... (and even) the supervision of government councils

36 J. D. Omer-Cooper, The Zulu Aftermath: A Nineteenth-Century Revolution in Bantu Africa (London: 1966), p. 181.

37 Ibid., p. 181 ; cf. B. G. M. Sundkler, Bantu Prophets in South Africa (London : 1961); E. Roux, Time Longer than Rope (London: 1964).

38 Uzoigwe, Revolution and Revolt, pt. 1.

39 Ibid., pp. 13-16. 
and administration of justice were given up to military influence." 40 Kabalega had deliberately set his territorial administrators and his new style generals against themselves. But he balanced the forces in such a way that the administrators still exercised considerable authority, if not effective power, since real power was bound to lie with the sword. And the sword, at this time, was strengthened by the addition of firearms.

In Buganda, Kabaka Mwanga created his version of the abarusura which has been described as "a new corps d'elite of fusiliers, who decided the issue of battles." 41 They differed from the abarusura in the sense that they combined the functions of the old provincial administrators as well as those of professional warriors. The difference, really, between the old and the new was not only in the locus of power but also in the class of the "new men" who led these forces and who by the last two decades of the nineteenth century wielded enormous influence in Kiganda politics even at the expense of the Kabaka himself. They began their career as young men most of whom had been educated as pages in the Kabaka's court where they had adhered to either Islam or Christianity depending on the predilection of the Kabaka at that time. It was Kabaka Mwanga who formed them into new regiments after the persecution of the Christians in 1886 as a counterweight to what he considered to be the reactionary forces of the old territorial rulers. Without destroying the ancient and welltested mechanism of territorial administration, Mwanga simply removed from the old civil-military barons of the kingdom the military power which was the source of their enormous influence. Unlike Kabalega, however, Mwanga was unable to manage the monster he had created and quickly fell prey to it. ${ }^{42}$

As a result of the nineteenth century civil war in Yorubaland, the military assumed unbridled influence in politics. The new warlords who rose to influence in this period used their private armies to reduce the traditional rulers as their puppets. The new-style warlords, quite different from the traditional Elegbe (warrior-chiefs), were usually young and ambitious men anxious to make a name for themselves in what they perceived to have been a new heroic age in Yoruba history in which heroism and military adventurism assured not only survival but also glory, honour, and wealth. They still recognised, however, the nominal sovereignty of their respective Obas; sometimes they gave them part of their booty; and in many cases their armies were used to defend or expand their Obas' territories. ${ }^{43}$ But yet, like the abarusura of Bunyoro, the "new men" the warlords - constituted a departure from customary practice as well as a

40 Gaetano Gasati, Ten Years in Equatoria (London: 1898), pp. 272-274.

41 Wrigley, "Changing Economic Structure of Buganda," p. 25.

42 This episode of Buganda's history ought to be well known by now. The most relevant works for our purposes, however, include J. A. Rowe, "The Baganda Revolutionaries," Tarikh 3, 2 (1970), pp. 34-35; D. A. Low, Buganda in Modern History (London: 1971), pp. 13-54; Michael Wright, Buganda in the Heroic Age (New York: 1971).

43 Akintoye, "Military Among the Yoruba," loc. cil.; idem, Revolution and Power Politics in Yorubaland (London: 1971); Smith, Kingdoms of the Toruba, pp. 120-129, 155-174; J. F. A. Ajayi and R. S. Smith, Yoruba Warfare in the 19th Century (Cambridge: 1964). 
challenge to the leadership role of the territorial administrators. But, unlike the abarusura, they were not a creation of the Obas. Their success in this confrontation was due to their possession of personal standing armies armed with firearms as well as with traditional weapons. The rise of the warlords, it has been argued, resulted in the loss of personal freedoms among ordinary citizens who, in search of security following the breakdown of law and order, sought the protection of powerful leaders who maintained their positions by force. ${ }^{44}$ With the advent of British rule ended the era of the great warlords in Yoruba history.

To summarize our sampling so far: the African warrior was a political animal more than the rest of the citizenry especially as the military and the state were dangerously fused; that the study of the warrior is tantamount, in fact, to the study of the state; that in the study of the state, the political function of the warrior was dominant in both national and territorial administrations; and that the rise of standing armies or professional warriors tended to upset the political balance. In the case of the Yoruba and Buganda, both the king and the old civil-military administrators became subjected to domination by their warriors; in Bunyoro and Zulu, on the other hand, only the old civilmilitary administrators of territories were reduced to a political cypher. There was an alliance between the military and the monarchy which gave rise to centralisation and stability. In all these developments, politics was so structured that the people could not change an oppressive government. Governments were of course overthrown, but these were usually "palace revolts" in which the position of the ordinary citizens did not change markedly. Politics among the Kikuyu was apparently more democratic than in the other samples. There was no king; there was no nobleman; there was neither a standing army nor professional warriors as such; and the individual citizen was an indivisible element of the government. Although our samples are understandably limited - but nevertheless carefully chosen - we may hazard the conclusion that the function of the warrior in precolonial Africa exhibited more similarities than dissimilarities.

\section{The Warrior in a Socio-cultural Framework}

The warrior tradition manifested itself also in a variety of interlocking socio-cultural and economic relationships within the social organisation of the state. The individual warrior, it must be understood, was, first and last, a citizen. He was therefore only significant in the context of the larger society. In short, he was subject to social manipulation by the state in the interests of statal stability and survival. This manipulation attempted to achieve several ends, the most important of which, at any rate, for our immediate purposes, included (a) the inculcation of the idea of a joint identity, common heritage, and common future (nationalism, patriotism); (b) the achievement of corporate alliances and other social arrangements (social transformation); and (c) educa-

44 Akintoye, "Military Among the Yoruba," cf. also Smith and Alayi in f.n. 43. 
tion with respect to guides and sanctions of a nationally or culturally accepted moral order (social therapy). The ultimate end of all these devices is to ensure social control. The warrior, then, must also be studied as social structure.

The extended family is the starting point of our analysis. It is not only the beginning of the political community but also the foundation of society. The African state is an organism growing out of the family; and the warrior, as we saw, is part of that organism. Among the Kikuyu, for example, the individual warrior is responsible to his Mbari or Nyomba (family group) through which he is responsible to his Moherega (clan) as well as to his riika (age-set). The activities of the warrior, his successes and failures, reflect on his Mbari and Moherega. Since the Kikuyu practice is almost universal throughout Africa, it will be superfluous to burden ourselves with further samples. It is the starting point of the education of the warrior. Notions of nationalism and patriotism are learned within the family group and extended to the wide society as we shall see. The state, then, is the extended family writ large.

The age-set and the circumcision guild constitute another form of social control which is crucial to our understanding of the African warrior especially in his relationships with the state. It is a widely adopted method of unifying the community and of determining status and behaviour patterns. It is a means for organising corporate alliances with the aim in view of not only achieving social transformation but also of organising the state for offence and defence. Kikuyu, once more, provides us with a good sample. Kenyatta writes: "the Mbari and the Moherega system help to form several groups of kinsfolk within the tribe, acting independently; but the system of the age-grading unites and solidifies the whole tribe in all its activities." 45 Kikuyu warriors were grouped according to their riika. Boys and girls became members of a riika by passing through the rite known as gotonya ndogera na mato (piercing of the ears). This was done between the ages of four and five. Then, between the ages of eighteen and twenty they undergo circumcision ceremonies. To become a warrior one must have performed these rites. The Kehee (uncircumcised person) was regarded as a coward, a social undesirable. According to Kenyatta:

He cannot build a homestead of his own. In the days of tribal war he could not go to the battlefield; he could only stay at home with the women and defend the homestead. He cannot boast or brag or even appear to do so. He is not allowed to wear the long hair of the mwanake, circumcised youth; it is taboo for him to have sexual intercourse with circumcised girls. In meat feasts, he is not allowed to eat certain joints; he cannot have a circumcised man as an intimate friend. In contrast with all this, the circumcised youth is a warrior, a dandy, a dancer, an eater of good food. He is full-grown, a proper man, a full member of the tribe. ${ }^{46}$

In short, a coward in a society such as this is, for all practical purposes, a non-person beneath the law. A circumcised Kikuyu, on the other hand, was regarded as a brave man and was called a mondomorome (a he-man); he was ad-

45 Kenyatta, Facing Mount Kenya, p. 4.

46 Ibid., p. 104. 
mitted to the njama ya anake a mumo (the national council of junior warriors) and introduced "into the general activities and etiquette of the warrior class". After this introduction, the leading warrior utters the rohio (a war cry) and the young warrior joins his companies in making the following mwehetwa wa anake (warriors' resolution):

We brandish our spears, which is the symbol of our courageous and fighting spirit, never to retreat or abandon our hope, or run away from our comrades. If ever we shall make a decision, nothing will change us; and even if the heaven should hold over us a threat to fall and crush us, we shall take our spears and prop it. And if there seems to be a unity between the heaven and the earth to destroy us, we shall sink the bottom part of our spear on the earth, preventing them from uniting; thus keeping the two entities, the earth and the sky, though together, apart. Our faith and our decision never changing shall act as balance. ${ }^{47}$

The young warrior then is allowed to demonstrate his skill in a mock battle. He has to wait, however, for "about eighty-two moons or twelve rainy seasons following the circumcision ceremony" for promotion to the rank of njama ya ita (council of senior warriors). ${ }^{48}$ At this point his formal education is over and he assumes the political and social positions for which he has been training since the age of four or five.

The social philosophy behind age-sets and circumcision rites is fascinating. A few more samples, therefore, will be worthwhile. The Tiriki of Kenya, too, had, for the sake of corporate unity, defence and offence, divided their male population into seven age-sets. They also practised circumcision which gave a ritual embodiment to the passage from boyhood to manhood. During the period of seclusion, lasting some six months, period the youth went through a carefully laid out programme to bring about social transformation. Communal undertakings were encouraged; individualism was discouraged. It took the young Tiriki some fifteen years, however, after the initiation ceremony before he was admitted to the rank of the warriors, the most admired honour for men in that society. Before attaining this honour, he must have demonstrated qualities of leadership, charisma, and prowess in conflict. By the age of forty he would be elevated to the status of elder warriors. At this point his formal education would be completed. It was these elder warriors, we are told, who actually ruled Tirikiland. ${ }^{49}$ Among the Tiriki, therefore, the warriors formed an elite set, a sort of military aristocracy, the elderly among whom controlled political power. As in Kikuyu, Tirikiland institutionalized and vigorously cultivated the warrior tradition. The warrior-politician manipulated Tiriki society to ensure its survival and thereby protected their position.

In Uganda the Bagisu are well known for the organisation of their society by age-sets through a ritual circumcision of boys and girls, very much in the

47 Ibid., p. 191.

48 Ibid., p. 192.

49 Basil Davidson, The African Genius: An Introduction to African Social and Cultural History (Boston: 1969), pp. 84-86. 
tradition of the Kikuyu, unlike whom, however, such a practice did not appear to have had much military significance. Of course, the Bagisu fought wars - or more likely battles - when the occasion demanded such a solution. But such occasions appear to have been very rare, and when they did occur, the wars or battles were of short duration..$^{50}$ The warrior tradition among the Bagisu was therefore weak. For the interlacustrine Bantu, on the other hand, where ritual circumcision was not practised and where variations of a centralized form of government were operated, the warrior tradition had more social significance. The ruling aristocracy of the conquest state of Banyankore, for example - the Bahima - dominated the more numerous Bairu until the colonial period, due, in part, to greater military cohesion and prowess in war. Through the existence of warrior bands, led by certain military chiefs who recognised the Omugabe (king) of Nkore as their sovereign, the Bahima aristocracy perpetuated the social domination of the Bairu. Marriage between a Mwiru and a Mukima was strictly prohibited, and the illegitimate offsprings between Bahima men and Bairu girls were legally classed as Bairu although they were called Abambari (half-castes). Their lot, however, as was usual in similar cases in other parts of the world, was better than that of the Bairu. A Mwiru was forbidden to kill a Muhima for any reason whatsoever while the same rule did not apply to a Muhima. The Bairu were forbidden to own "productive cows"; but they were ruthlessly exploited through the imposition of food and labour tribute. ${ }^{51}$ The military in Nkore was an instrument of class and social domination in precolonial Uganda.

Before the Mfecane, the Nguni regarded the age-set rite and ritual circumcision as a sacred institution. The Nguni age-set organisation or circumcision guild differed, however, from the others we have discussed so far in one important respect: each age-set was associated with a royal age-mate who led his peers in war and peace. But the principles of the institution as well as the concomitant rite of circumsision was similar. ${ }^{52}$ During the Mfecane, as we shall see, the age-regiment replaced the age-set; circumcision was abandoned, and society took a more military character.

The age-set organisation appears to have been better developed - in terms of its structural-functional significance - in eastern African and Bantu southern African societies than in those of West-Africa. Circumcision, for example, among the Igbo or among West African Muslim communities has no discernible military or age-set connotation since it was carried out within the first two weeks of a child's birth. The age-set organization existed to perform several social functions, the military aspects of which, though important, were not particularly pronounced. Among the Yoruba, on the other hand, the lineage and ageset systems did provide, to some degree, the social machinery for defence and

50 John Roscoe, The Northern Bantu (London: 1915 and 1966), p. 190.

51 K. Oberg, "The Kingdom of Ankole in Uganda," in Fortes and Evans-Pritchard, African Political Systems, pp. 121-136.

52 Omer-Cooper, Zulu Aftermath, pp. 27-28. 
offence within the various state systems. Members of a lineage lived in an Agbo-Ile (compound) under the leadership of a lineage head, usually the eldest member of the lineage. The age-sets were formed from several lineages to perform social functions similar to those performed by Kikuyu age-sets. In wartime, the age-sets were led by the Elegbe chiefs. As a result of the nineteenth century civil wars, the warriors came to assume greater social significance. The age-set, as a machinery for achieving social cohesion, joint identity, common heritage and common future, broke down. Ibadan led the way in this transformation. Here, the civil war had given rise to prominent warriors who headed their own armies. It is true that the nucleus of each war leader's army still came from his own lineage or village, but as the civil war progressed, the ranks of this army were swollen by the process of accretion. The new additions included war captives as well as free men from various parts of Yorubaland (especially refugees), "who, eager to share in the greatness [of the warlord]" as well as in his successes and in his protection, "willingly attached themselves to him." They were settled in an Agbo-Ile belonging to the warlord. In a sense, then, an Ibadan army did not exist; there existed only a band of warriors "each owned, led, and provided for by its chief." ${ }^{53}$ It would appear that a client captive or free - after making a name for himself in this sort of military activity, would return to his own home and raise his own personal army in the tradition of his former Ibadan overlord. In this way, what has been described as the "Ibadan System" gradually spread throughout Yorubaland during the nineteenth century. These warlords forced their followers to cultivate large farms for the purpose of producing food for sale, to engage in trade in order to raise revenue, including the distribution of imported goods. Nineteenth century Yoruba history is full of examples of outstanding warlords whose versatility, ambition, greed and restlessness made war a permanent necessity. War became a necessity for a warlord not only for the purpose of keeping his warriors constantly occupied but also for increasing his following (since a large, well trained and well led following ensured survival in this dangerous and highly competitive age); it was essential for the purchase of arms and ammunition to be used in the execution of further wars. Success bred success; failure meant death or enslavement. The rise of the warlords altered social relationships in Yoruba country by successfully challenging the social and political dominance of the traditional rulers who were now their puppets. But it also resulted in the loss of personal freedoms among ordinary citizens who, in search of security and livelihood following the breakdown of law and order, sought the protection of powerful individuals. It was the British conquest of Yorubaland which brought to an end the era of the great warlords in Yoruba history. ${ }^{54}$

The age-set organisation does not appear to have existed among the Akan of Ghana. However, the asafo (military organisation of the towns) and the abusua (clan system) seem to have performed a similar function. "Every Agona

53 Akintoye, "Military Among the Yoruba," loc. cit.

54 Ibid. 
(and for that matter every Akan)", writes Maxwell Owusu, "belongs to some asafo on the father's side (patrilineally) as he or she belongs to an abusua on the mother's side (matrilineally)." 55 The asafo, nevertheless, seems to have been most developed among the Fante. It comprised both men and women but only the men engaged in its military activities. The asafo is a social and military institution through which individuals who proved themselves in battle were rewarded with honours including chieftainships. ${ }^{56}$ It was aimed not only at demonstrating common identity but also at ensuring the stability, survival, and power of the Akan states, thereby promising a common and bright future. We shall return to the asafo presently.

Suffice it to say, in summary, that the asafo, as a social control system, performed similar functions as the age-set, the age-regiment, and the circumcision guild. All these systems are significant as instruments of primodial nationalism and patriotism, social transformation, and social therapy. In short, we are dealing with social manipulation at its best. And, in the final analysis, society is broadly manipulated for offence and defence.

\section{The Organisational Dimension}

Most studies of the precolonial African military are concerned with the military organisation of individual state systems. These studies, provided mainly by anthropologists, are usually sketchy and largely descriptive. Few comparisons are attempted. In a recent sampling of precolonial African military systems, however, Claude Welch, noted in an otherwise useful study, what he saw as "the extraordinary variations in African military organisation." 57 I think this is a gross exaggeration. Varieties certainly there were; but there was nothing extraordinary or dramatic about them. If our contention is correct, namely, that African military organisation followed closely the organisation of the state, and if this state organisation can be broadly classified - as is usually the case - into centralised, semi-centralised (semi-segmentary), and noncentralised (segmentary), military organisation ought therefore to reflect these three broad distinctions. And even if we added to these three categories Aidan Southall's intriguing as well as baffling notion of "segmentary kingdoms", we can hardly assert that precolonial African military organisations are myriad. On the contrary, similarities in organisation are more common than dissimilarities. In this section our sampling will be more extensive than hitherto and, inevitably, less detailed. The organisational dimension of the African military may be studied under the following aspects: Leadership and Command Hierarchy; Recruitment and Mobilisation; Technology, Training and Tactics.

55 M. Owusu, Uses and Abuses of Political Power: A Case Study of Continuity and Change in the Politics of Ghana (Chicago: 1970), p. 41.

56 For a study of the Asafo system see Ansu K. Datta and R. Potter, "The Asafo System in Historical Perspective," 7.A.H., XII, 2 (1971).

57 C. Welch, "Continuity and Discontinuity in African Military Organisation," 7.M.A.S., 13, 2 (1975), p. 235. 
Leadership and Command Hierarchy. Leadership in war, even when it resided in the dominant group within the state system, on heredity, or is clan based, was generally entrusted to the most capable hand among the privileged. It is, indeed, part of the command hierarchy which follows closely the state organisation. Among the so-called egalitarian Igbo, for example, leadership in war was not hereditary. It was earned on merit, that is, proven ability in battles, including demonstrable excellence in the mastery of the martial arts. ${ }^{58} \mathrm{I}$ have no information, however, to suggest that an Osu (untouchable?) or Ohu (slave?) was ever made the generalissimo. They did fight with the rank and file citizens and were rewarded according to their merit. The essential point here is that leadership in war is a function of the Igbo political organisation. But the issue of ability and excellence among the privileged as the prerequisite for leadership is also true of the Kikuyu Acholi, Bunyoro Kitara, Buganda, Nkore, Zulu, Ndebele, Rwanda, Akan, Oyo, Tukulor and so many others. The morality of dividing society between privileged and unprivileged classes is not here my concern. The point I wish to stress, however, is the similarity of the leadership ideology within states of differing political organisation.

In Bunyoro Kitara, the Omukama was the commander-in-chief of his warriors, and the territorial administrators, as we saw, comprised what might be called the officer class. Together they led the citizen militia in war and ruled them in peace. When, as a result of widening responsibilities and internal problems he was forced to surrender field command to his military chiefs, his political effectiveness declined; and by the middle of the nineteenth century, the great Kitara empire had become a shadow of its former self. Kabalega's creation of the abarusura, as we also saw, was intended to check the dominant influence of these military chiefs. This policy naturally involved a change in command hierarchy. All the commanders, for example - with the exception of three ${ }^{59}$ (whose loyalty was not in doubt) - were no longer territorial rulers; equally importantly, every commander could be transferred from one command to another which meant that the command was no longer, as in the past, a sort of territorial fief. The generalissimo, too, was no longer necessarily the most important and able territorial ruler. Military command and territorial rulership, in short, had become separable. In Bunyoro, at any rate, change in military organisation affected decisively power relationships within the state. ${ }^{60}$

This is also true of the Zulu and the Ndebele. The barrack system which Kabalega developed in the second half of the nineteenth century, had earlier been developed by Shaka. I have no reason to believe that Kabalega copied

58 S. C. Ukpabi, "The Military in Pre-Colonial Igboland," The Accra Conference, August, 1975.

59 These were Nyakatura Nyakamatura, Ireeta Byangombe, and Kikukuule Runego. These important personalitics had helped put Kabalega on the throne during the succession war of 1869-1871. He therefore rewarded them by appointing them abarusura generals while allowing them to retain their chiefly responsibilities as well.

60 Uzoigwe, Revolution and Revolt, pp. 1-29; idem, "Kabalega and the Making of a New Kitara," pp. 5-20. 
this system from Shaka. But the introduction of the barrack system in Zululand also changed power relationships, especially command hierarchy. During the Mfecane, and as a result of increasing military insecurity, the Mthethwa (under Dingiswayo), the Ndwandwe (under Zwide), the Ngwane (under Sobhuza), and the Pondo were forced to abandon the sacred rite of circumcision whose ritual seclusion tied up a significant flighting force in times of crises, and changed the age-sets into age-regiments. It was Shaka, however, who perfected the ageregimental organisation. The regiments, unlike those we have studied so far, were not grouped according to clan ties. They were, on the contrary, transethnic and "national" in composition. They were forbidden to marry until they reached the age of between thirty-five and forty years at which period they were permitted to marry from a regiment of girls of between twenty-three and twenty-five years of age. Both the regiment of boys and the regiment of girls as well as royal Zulu women were housed in barracks. These innovations, in addition to the military tactics developed by Shaka, were the most important contributions he made to the social history of the southern Bantu. The great Mzilikazi Kumalo, king of the Ndebele, conqueror of the Shona, and founder of what later came to be called Rhodesia instead of Mzilikazia (Zimbabwe), did not establish the barrack system (within which he was schooled) in his new kingdom. Nor, indeed, did he enforce celibacy for himself or his warriors. But, then, his problems were different from Shaka's; on the contrary, he used his regiments as an army of occupation. ${ }^{61}$ Barrack existence and celibacy were seen by Shaka as a conditio sine qua non for military discipline. It is remarkable that these soldiers did not practise homosexuality. Everyone, except the diviners or the infirm, belonged to a regiment. ${ }^{62}$ The Zulu were definitely a "nation in arms". The Zulu state was a timarchy, the like of which Africa had not seen before and probably would not see again. The territorial chiefs of earlier days were no longer significant in the new scheme of things. By the second half of the nineteenth century when the Zulu military machine reached its perfection, it seems reasonable to assume that the territorial chiefships were occupied by retired warriors.

Command hierarchy among the Ndebele was an elaborate administrative system. Matabeleland consisted of four imikhono (saza in Runyoro; provinces or countries in English) which also coincided with the four divisions of Mzilikazi's army. Each imikhono was administered by an induna Nkulu (senior chief); it was also divided into districts which, except for those under the control of the chiefs of the conquered and assimilated Shona, coincided with the impi (regiments) of the army. There was also the buto (military regimental town) which was under the control of the induna yabuto (commanding general). But there were usually also, in each buto, an induna Umuzi who was in charge of civilian

61 Gluckman, "The Individual in a Social Framework," loc. cit., p. 139.

62 E. J. Krige, "The Military Organisation of the Zulus," in Elliot P. Skinner (ed.), Peoples and Cullures of Africa (New York: 1973), p. 484; $f f$. James Stuart, History of the Zulu Rebellion 1906 (London: 1913), esp. p. 72. 
as opposed to military matters. Below both indunas were the abalisa (battalion commanders); and above the indunas was the Nkosi (king) himself. ${ }^{63}$ The structure of Matabeleland was, like that of Zululand out of which it grew, simply the structure of an army. In war and peace, the Nkosi, like the Omukama of Bunyoro or the Kabaka of Buganda, was a centrifugal as well as a centripetal force in the kingdom. But neither Bunyoro nor Buganda was militarized to the extent that Matabeleland was.

Among the Akans command hierarchy also followed the state administrative pattern. Maxwell Owusu, writing about Agona states: "The organisation of stools and swords in Agona is nothing but military formation based on the logistics of war developed by the people. Political organization is ipso facto military organization." 64 This statement may well apply to all the Akan states generally. Among the Asante, for example, the members of the oman nhyiama (ruling state council), for example, also headed the military divisions of the state. The Asantehene (king) held the position of supreme commander of the army; two of his deputies who administered the state in his absence, the Kontihene and the Akwamuhene, were also the first and second war chiefs respectively. Below them were the Adontenhene (commander of the main force - "the carrier of the foot of the Omanhene"); Nifahene (right wing); Benkumehene (left wing); Kyidomhene (rearguard); and Gyaesehene (Omanhene's bodyguard as well as the head of the domestic bureaucracy). Here, once again, is a dangerous fusion of military and political functions. These leaders, too, except in a few cases, were also either lineage heads or chiefs of provinces. In peacetime, they managed the state apparata; in wartime, they took all decisions including the prosecution of the war itself as well as the making of peace. ${ }^{65}$ These samples will suffice to show that the command hierarchy in the kingdom states of Africa reflected the political organisation of the states. Minor variations occurred here and there, but there was really nothing dramatic about these variations.

Igboland, on the other hand, which included both the characteristics of the semi-kingdom and non-kingdom state systems, does vary from the classic kingdom states but only because of the varying political structure. Among those uninfluenced by kingdom characteristics, the war commander was usually appointed by the consensus of the warriors prior to their departure for the battlefield. The commander, called Ochiagha (leader in war), was always someone whose warrior reputation was already secure; but during his tenure he must continuously live up to that reputation or yield his place to a more deserving comrade. The Ochiagha commanded the centre in battle. He was assisted by two other commanders, also appointed by consensus because of proven ability,

63 David Chanaiwa, "The Army and Politics in Pre-Industrial Africa: Ndebele Nation 1822-1893," Accra Conference, August, 1975.

64 Owusu, Uses and Abuses of Political Power, p. 39.

65 Agnes A. Aidoo, "The Role of the Military in Politics and Society in 19th Century Asante," Accra Conference, August, 1975; Kwame Arhim, "Asante Militarism: A Preliminary Note," Accra Conference, August, 1975; cf. Owusu, op. cit., pp. 39-40. 
who commanded the right and left flanks respectively. ${ }^{68}$ The Ochiagha was responsible to no one but to his village or town. Among Onitsha, Oguta and Aboh Igbo - areas influenced by kingdom characteristics - there was also always a commander-in-chief called the Iyase. But he wielded no more authority than the Ochiagha. ${ }^{67}$ Like the Igbo Council of Elders, the Acholi rwot (lord or clan leader) and his counsellors and other advisers were not military men per se. They concerned themselves with civil matters although they decided when to go to war and when to make peace. But the general was chosen in peacetime by censensus. He had a free hand in the prosecution of war. The civilians, however, made decisions regarding the spoils of war. ${ }^{68}$ The Acholi, like the Igbo, believed in specialisation and division of labour.

Recruitment and Mobilisation. Except in a few cases, and mostly during the nineteenth century, African warriors were assembled ad hoc to deal with specific emergencies or to execute certain state objectives. They were agriculturists, pastoralists, artisans, administrators, etc. who reverted unobtrusively to their occupations as seen as the campaigns were over. In short, every able-bodied male of military age was a soldier in addition to his other occupations. In some societies, Igbo ${ }^{69}$ and Dahomery, for example, females participated in the fighting but there was no general mobilisation among them; in most societies, however, women contributed indirectly but significantly to the war effort. There were, of course, certain states - usually conquest states - which adopted the principle of differential recruitment by linking class with military specialisation. This was true of the Mossi where only the noblemen served in the cavalry and commoners served as infantrymen; and in major battles, infantry was only auxiliary to cavalry. But yet all able-bodied males of military age went to war. It has also been noted among the Hausa, slaves dominated the infantry and formed a considerable part of the cavalry as well. Here, therefore, differential recruitment was mitigated somewhat. For the Wolof in the nineteenth century the bulk of the warriors were thiedos (unbelievers) who served under the command of village chiefs. ${ }^{70}$ The pattern of social dominance was such, however, that the thiedos could not overthrow the theocratic state system. In Rwanda, the reverse was the case. The dominant Batutsi (pastoralists) used differential recruitment as one of the means of perpetuating their dominance over the Bahutu (agriculturists). And although by the nineteenth century certain Bahutu such as Bisangwa and Bishingwe rose to be military commanders, the

66 Ukpabi, "The Military in Pre-Colonial Igboland", loc. cit.

67 Ibid.

68 John O. Dwyer, "Acholi Military History", African Studies Association Conference paper, Philadelphia, 10 November 1972.

69 The role of Dahomeian women in war is well known. For Igbo women see Paul Edwards, Equiano's Travels (London: 1967), pp. 9-10.

70 Welch, "Continuity and Discontinuity in African Military Organisation", pp. 232-233; cf. Elliot P. Skinner, The Mossi of the Upper Volta: The Political Development of a Sudanese People (Stanford: 1964), pp. 97-106; M. G. Smith, The Economy of Hausa Communities of Zaira (London: 1955), p. 10. 
fact remained that the Bahutu did not generally form part of the state itero (military units). The Batwa (pigmies), too, could only serve as the Mwami's (king's) personal bodyguards, as bodyguards of important chiefs, and as warriors outside the itero organisation. ${ }^{71}$ We have also noted that in those societies where military service depended on circumcision and age-sets, individuals who failed to perform these necessary rites de passage were also affected by differential recruitment. In terms, however, of the generality of African state systems, recruitment and mobilisation patterns were more simular than dissimilar. Among the states which developed standing armies, ability, loyalty, and bravery rather than class differentiation seems to have determined a warrior's future in the military hierarchy. Indeed, Shaka or Kabalega would go out of his way to hunt down and kill a disloyal warrior or one who was convicted of cowardice; they would also reward generously a loyal and outstanding warrior irrespective of his class.

Technolog', Training and Tactics. The impact of technological innovation on the histories of nations cannot be overemphasized; but it is also apt to be misunderstood. Superior military technology is not only an instrument of imperial domination but also one of internal coersion. More importantly, it is an instrument controlled by the ruling elite. Where centralised control is impossible as in the case of the "democratic" bow and arrow, the state manipulates its use through specific acts of social and political engineering. But since the ruling elite of precolonial African states comprised also the warriors, it means that precolonial African history was characterised by a dangerous fusion of politics and violence. In both the colonial and postcolonial periods of African history, such a trend has continued unabated. A colonial situation was created by violence and maintained by violence or the threat of it - whatever the apologists of colonialism may say. Independent African states - and I am really hard put to make an exception here - even where the military is not exercising open power, have tended to show less restraint in the use of violence to ensure individual, particularist, ethnic, or state ends. The warrior, then the soldier, has become more and more, not the instrument of defence and offence, but an instrument of coercion. Indeed, I think it is fair to say that precolonial African states, in spite of their dangerous fusion of politics and the military, in general used less physical coercion than the colonial and postcolonial states; but they were more adept at politico-socio manupilation than their twentieth century successor states.

What is easily noticeable about precolonial African military technology is its simplicity. For our immediate purposes, however, what is intriguing is the similarity of the military technology of these African state systems as shown below:

71 Welch, "Continuity and Discontinuity," pp. 233-234; cf. J. J. P. Maquet, The Premise of Inequality in Ruanda: A Study of Political Relations in a Central African Kingdom (London: 1961), pp. 109-10. 


STATE
Acholi
Buganda
Bugisu
Bunyoro Kitara
Hausa
Igbo
Ndebele
Tukulor
Yoruba
Zulu

\section{TECHNOLOGY}

Shield, spear, knife

Shield, throwing spear, stabbing spear, fircarms (19th century)

Shield, spear, knifc

Shield, throwing spear, stabbing spear, bow and arrow (used only by the fishing community of Bugungu), firearms (19th century)

Shield, horse, sword, bow and arrow, firearms

Shield, spear, bow and arrow, dagger, spiked club, matchets, steel knife, firearms

Shicld, throwing assegai (spear), stabbing spear, firearms (19th century)

Shicld, horse, sword, firearms

Shield, spear, bow and arrow, sword, horse, fircarms

Shield, throwing assegai (spear), stabbing assegai, firearms (19th century)

From the above sampling carefully selected to reflect ecological, regional, and constitutional variables, we may arrive at the following conclusions. First, precolonial African military technology was very rudimentary and shows more similarities than dissimilarities. Shields and missiles provide the common denominator. Second, it follows therefore that in either offensive or defensive war, training, tactics, cohesion, leadership, discipline, martial spirit, numbers, and geography, in varying ways, would seem to be more crucial than technology. Hausa horsemen, for example, fighting in the forest areas of Igboland, would not have a ghost of a chance. Nor would Igbo warriors fare any better in the grassland against the Hausa. Third, firearms were fairly well spread, at any rate, by the nineteenth century. But their use by no means discouraged the use of other weapons. Indeed, my studies in East Africa demonstrate that the impact of firearms on the outcome of battles has been exaggerated. Nor did firearms necessarily prove a worse instrument of coercion in the period under survey than the other military technologies. Shaka's Zulu, we know, did not use firearms; and yet his Zulu state was the most coercive state in nineteenth century Africa. And fourth, the crucial point to note in any discussion of the warriors and the state is not only the novelty of the technology available to the state but also - and more importantly - who controlled what technology there was, how effectively it was controlled, and to what end.

In this consideration the nature of the socio-political structure of the states, as we have shown, becomes crucial. Religion, not firearms, ${ }^{72}$ led to the rise of bureaucratic states in the central Sudan during the nineteenth century; and it was the quality of Shaka's military leadership and military tactics that proved more crucial as centralising modes than the mere introduction of the assegai. Indeed, the assegai, as a technological innovation, cannot be attributed to Shaka. It was a weapon with which the Zulu were already familiar. Shaka's

72 Joseph P. Smaldone seems to argue the contrary. See "Firearms in the Central Sudan: A Revaluation", J.A.H., XIII, 4 (1972); $c$. idem, "Military Organisation, Warfare, and Sudanic State Structure: Some Sociological Aspects of Technological Change," African Studies Assocation Conference paper, Philadelphia, 10 November 1972. 
great military contribution, therefore, was in the areas of tactics and training. Even under Shaka, a warrior carried both his throwing spear and his stabbing spear. The stabbing spear, as we saw, was also familiar to the Baganda and Banyoro. And yet East African historians have not made much noise about its existence. The reason, I suppose, is because the East African warriors were unable to put it into the revolutionary use to the extent that Shaka did. The difference between, say, Zwide's warriors and those of Shaka was that the latter were better trained, better disciplined, and better led. The standing army created by Shaka was also a tactical innovation designed to ensure discipline and the enhancement of his power which were crucial for empire-building. In Bunyoro, Kabalega who bears comparison with Shaka in several respects, was nonetheless not a military genius; but he was a great warrior who realised, as did Shaka, that the army was the instrument to maintain state, and consequently, royal power. His formation of the abarusura was a significant military development in the interlacustrine region. It was a tactical contribution designed to subdue overmighty subjects, pick up the pieces of the practically disintegrated Kitara empire, check the prospering ambition of Buganda, and if possible, recreate the old Kitara empire. Finally, it is in the area of systematic, sustained military training that precolonial African warriors were least deficient. Technological innovation, unsupported by adequate training and tactics, loses its effectiveness.

\section{Conclusions}

This chapter is a contribution to the study of the precolonial African military as an indispensable aspect of African history. The images of the warrior are not its theme. On the contrary, it is a comparative study of the institutionalfunctional aspects of defence and offence among carefully selected precolonial African state systems. It aspires, however, to be no more than an introduction a prospectus, if you will - to a field of research that promises a bright future ahead of it. The information at my disposal, nevertheless, has led to certain conclusions which further, more systematic, researches may well modify or even confirm; first, that the study of the precolonial African military is the study of the structure of African history itself. Therefore, a military interpretation of African history should prove as rewarding - or even more rewarding - than the prevailing interpretations. Second, the African warrior was a political animal par excellence particularly because of the fusion of the state and the military. The study of the warrior, then, is tantamount to the study of the state. And since the Africans saw the state as organism, the warrior, too, must be studied as organism. The ambitious youth was well aware that excellence as a warrior was an impeccable passport to important political offices, wealth, glory, honour, themselves part of the equation. The warrior tradition was the bedrock of statehood; and politics, in short, was organised around the warriors. Politics, law, and the instruments of destruction resided in the same hands. Prima facie, this was an unhealthy development especially as the warrior was dominant in both 
national and territorial administration. The ordinary citizens had no means of overthrowing unpopular military-civilian governments in the kingdom states. Palace rebellions, sometimes leading to changes in personnel, did, of course, occur from time to time; but the structure of government hardly changed. The rise of standing armies and professional warriors in the nineteenth century did, indeed, upset the political balance; but politics remained structured in such a way that the people could still not change an oppressive government. Nevertheless, few governments were ever as oppressive as the colonial or the postcolonial governments. Among non-kingdom states such as the Kikuyu and the Igbo, the myth that the ordinary citizen was an indivisible element of government was so astutely cultivated that the overthrow of those who controlled power was considered unnecessary. This brings us to our third conclusion, namely, that the warrior was, first and last, a citizen. His education was a brilliant lesson in social manipulation and social control. The sacred notion of the extended family, the rites des passage of age-sets and circumcision guilds, and age-regiments (whether they be of the variety perfected by the Zulu or the asafo of the Akans) were all intended to inculcate the idea of nationalism and patriotism, to achieve social transformation, and to act as social therapy. In the final analysis, the philosophy behind these social institutions is a broad manipulation of society for offence and defence in the interests of stability, survival, and prosperity of the state. Fourth, since the organisation of the military followed closely the organisation of the state, and since the organisation of African state systems are reducible to three broad categories, the dramatic variations that are supposed to characterize precolonial African military organisations are fictitious. Within the broad categories differences did exist, but there was nothing extraordinary about them. On the contrary, the precolonial African military organisation - and indeed the military in general - exhibits more similarities than dissimilarities. And fifth, to understand fully the military in contemporary Africa, the character and nature of the military in precolonial Africa must first be comprehended. It is only then that the question of continuities and discontinuities in the African military tradition which is now attracting some attention can be more fruitfully tackled. It is hoped that this study has made a small contribution - in spite of its weaknesses - in that direction. 